\title{
Effect of the Amount and Timing of Ammonium sulfate single top-dressing application on growth and yield of Akitakomachi rice (Oryza sativa L.)
}

\author{
Claurence Nkumbe Ndille ${ }^{1 *}$, Edward Munyonyela Lena ${ }^{2}$, Isaac Mupeta ${ }^{3}$, Njukeng Jetro Nkengafac $^{4}$ \\ ${ }^{1}$ Institute of Agricultural Research for Development \\ Cameroon \\ ${ }^{2}$ Kilimanjaro Agricultural Training Centre (KATC) \\ Tanzania \\ ${ }^{3}$ Crops Section, Ministry of Agriculture \\ Republic of Zambia \\ ${ }^{4}$ Institute of Agricultural Research for Development \\ Cameroon \\ *Corresponding author's email: clarencendille [AT] yahoo.fr
}

\begin{abstract}
The effect of the amount and the timing of single top-dressing application of Ammonium sulfate fertilizer on the growth and yield of Akitakomachi rice (Oryza sativa L.) was investigated in this study. Two amounts

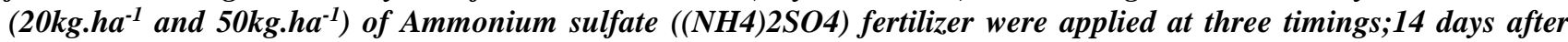
transplanting, panicle initiation, and flowering respectively, giving six treatments (14DAT:20, 14DAT:50, PI:20, PI:50, FL:20 \& FL:50). A Randomized Complete Block Design (RCBD) with three replications was used. Growth data were collected on plant length, number of tillers and leaf color, and calculated yield and yield components were determined. Plant length was significantly higher in 14DAT:50 and PI:50, and lowest in FL:20 and FL:50. Tiller number was higher in 14DAT:50 compared to the other treatments. 14DAT:50 and PI:50 produced the highest number of panicles per $\mathrm{m}^{2}$. PI:20 and PI:50 had the highest number of spikelets per panicle. The 1000 grains weight was highest in PI:50 and lowest in 14DAT:50. The highest yields were obtained in 14DAT:50 and PI:50, while FL:20 and FL:50 produced the lowest yields. The results showed that for nitrogen $(N)$ single top-dressing application, high amounts increase both the plant growth and the grain yield if the application is done at vegetative stage or at panicle initiation stage. However, if the nitrogen ( $N$ ) amount is too high, there exist the risk that the plants may lodge.
\end{abstract}

Keywords--- Oryza sativa L, Nitrogen Amount, Nitrogen Timing, Growth, Yield Components

\section{INTRODUCTION}

Rice (Oryza sativa L.) previously considered to be the staple food only for the people in Asia, has nowadays become the major food crop on which almost the entire world depends for food calories supply. Rice consumption has exponentially increased in the world over the past two decades. At present, more than half of the world population eats rice as staple food (Muthayya et al.,2014). With the world populations estimated to reach 9 billion people by 2050 and considering the major role rice is now playing in people's nutrition across the world, it is imperative that rice production must increase by at least $50 \%$ to feed the world population in the future (FAO, 2008). Rice production can be increased either by expanding land under cultivation or by increasing the yield of rice per unit area (Tang et al., 2017). However, due to urbanization, climate changes and the decrease in agro-climatically best suited land areas for rice cultivation, the most efficient and sustainable way rice production can be increased is by increasing the yield of rice per unit area. Previous studies have shown that, rice yield must increase by at least $1 \%$ every year to meet with the growing demand for food due to population growth and economic development (Normile, 2008). Of the multiple yield improvement practices that exist, like the use of high yielding varieties, irrigation, planting density and seedling age, the use of fertilizers is the most widely adopted practice, and the most effective. Nitrogen $(\mathrm{N})$ fertilizers are the main type of fertilizers that are used during rice cultivation. In Asia which has the highest production of rice in the world, it is reported that, the high yield levels of rice grains achieved currently are because of excessive use of nitrogen fertilizers (Ladha \& Reddy, 2003; Samonte et al., 2006). In China, the use of high amounts of nitrogen fertilizers is reported to have become a common practice for agricultural production (Gong et al, 2011; Ju et al., 2015; Tian et al., 2016). This massive adoption of nitrogen fertilizer is explained by the fact that, of all the nutrient elements that are required for plant growth and development, nitrogen $(\mathrm{N})$ is the most 
important and often the main limiting factor for adequate growth and development of plants (Kant, 2018). Nitrogen (N) plays a determining role in crop production due to its key intervention in the biomass accumulation process (Salvagiotti \& Miralles, 2008). Nitrogen $(\mathrm{N})$ constitute a building block for plant protoplasm and acts as a catalyst for other nutrients. Furthermore, nitrogen is reported to be the most active factor that determines soil fertility (Agreen, 1985; Cassman et al.,2002). Numerous studies have illustrated the importance of nitrogen $(\mathrm{N})$ fertilizers application in rice cultivation. Some studies have reported that, rice yield is significantly improved when nitrogen $(\mathrm{N})$ fertilizers are applied during cultivation (Cassman et al.,2002; Guo et al., 2010). Nitrogen is also reported to be a key element in the rice grain filling process which determines grain yield and quality (Gregersen et al.,2008). Although nitrogen (N) fertilizers are reported to be especially important in rice cultivation, the amount, and the timing at which they should be applied are still to be fully clarified. Some studies have reported that, the milling properties, the nutritional qualities of rice grain and the yield potentials could be achieved with late nitrogen fertilizer applications (Consuelo et al.,1996). Also, an increase of 20-60\% of the activity of phosphoenolpyruvate carboxylase (PEP carboxylase) enzyme, which results in an increase in protein and amino acids contents in rice gains, was achieved by applying nitrogen fertilizer at flowering stage (Sugimoto et al., 1997). Other studies have reported the need for nitrogen fertilizer applications to be done during the panicle initiation stage of the rice plant. An increase in rice spikelet number and yield was reported for nitrogen $(\mathrm{N})$ fertilizer top dressing application at panicle initiation stage (Ding \& Maruyama, 2004; Kamiji et al.,2011). Lee et al., (2008) reported that, the most effective timing for nitrogen top dressing application in rice is during the panicle initiation stage. Furthermore, other studies have reported that the most adequate timing for nitrogen top dressing application during rice cultivation is at vegetative stage. Tayefe et al., (2014) reported that, applications of nitrogen $(\mathrm{N})$ fertilizer at the vegetative stage of rice plants increased the number of panicles per $\mathrm{m}^{2}$ and increased the yield of rice grain. Additionally, it was reported that, to optimize the effects of nitrogen fertilization on rice yield, applications should be done at four or more doses throughout the rice growing season, (Xiong et al., 2018; Xu et al., 2015). Similarly, studies have investigated the amount of nitrogen (N) fertilizers to be applied during rice cultivation. Some studies have concluded that, to increase rice yield, high amounts of nitrogen (N) fertilizer should be applied during rice cultivation (Zhang et al.,2015; Zheng et al., 2016). Meanwhile, other studies have reported that high amounts of nitrogen fertilizer application could cause the plant to lodge and significantly decrease the rice yield. Also, some previous research results revealed that, excessive nitrogen fertilizer application during rice cultivation significantly reduces rice quality (Zhu et al., 2017; Carly et al.,2009). Furthermore, it is reported that, applications of high amounts of nitrogen fertilizer in an unchecked manner is detrimental to the rice plant and to the environment (Guo et al., 2010; La Croix et al., 2005; Liu et al., 2013; Tan et al., 2011). Additionally, extremely high amounts of nitrogen (N) fertilizers applications may result in the modifications of the soil productivity by altering microbial communities (Xun et al., 2016). Also, a significant positive correlation has been reported to exist between nitrogen leaching and the rate of nitrogen applied (Li et al., 2007). Moreover, some studies have concluded that, no proportional increase in grain yield is observed when the amount of nitrogen fertilizer application is increased (Huang et al., 2007; Yan et al., 2009). Nitrogen Use Efficiency (NUE) is reported to be low in rice plant because rice plant uses only 20-30\% of the applied nitrogen fertilizer (Peng et al.,2006), therefore applying nitrogen fertilizer at the appropriate amounts and at the right timing could improve rice NUE and subsequently the rice grain yield. Studies have also shown that morphological mechanisms of rice yield are increased significantly when nitrogen (N) fertilization is done in an optimized manner (Zhou et al., 2017). NUE depends largely in the nitrogen management practices especially the rate and the timing of nitrogen (N) fertilizer application (Ju et al., 2009; Yan et al.,2009; Peng et al.,2006). This study will investigate the combine effect of the amount and the timing of a single top-dressing application of nitrogen $(\mathrm{N})$ fertilizer on the growth and the yield components of rice.

\subsection{Study site}

\section{MATERIALS AND METHODS}

The research was conducted at the rice experimental field (RE-3) of Tsukuba International Center of Japan International Cooperation Agency (JICA), Tsukuba City, Japan located at $36^{\circ} 12^{\prime} \mathrm{N}$ Latitude, $140^{\circ} 0559$ longitude and at $33 \mathrm{~m}$ altitude. The work was conducted from April 2018 to October 2018.

\subsection{Plant material}

A Japonica type rice (Oryza sativa L.) Akitakomachi was used for this experiment. Rice seeds were selected using a salt solution of 1.13 specific gravity measured with a hydrometer. Selected seeds were disinfected by soaking them into a mixture of Benlate- $\mathrm{T}$ (Thiram-benomyl mixt) fungicide at $0.5 \%$ of 100 grams with 20 liters of water for 24 hours. About 600 grams of treated seed were then soaked in water at $17^{\circ} \mathrm{C}$ for six to seven days for pre-germination. Pre-germinated seeds were then sown into soil containing nursery boxes of $60 \mathrm{~cm} \times 30 \mathrm{~cm}$ dimensions at the rate of $50 \mathrm{~g}$ per box. The nursery boxes were placed in a greenhouse for seedling raising and management.

\subsection{Field preparation}

The experimental field (RE-3) of dimensions $28.7 \mathrm{~m} \mathrm{x} 14.7 \mathrm{~m}(421.89 \mathrm{~m} 2)$ was plowed using a tractor. A power tiller machine was later used for a second tilling to loosen the soil. Soil Samples were collected for chemical analysis of total carbon content, total nitrogen content, available phosphorous, exchangeable potassium, and pH (Table 1) at JICA 
Tsukuba Soil laboratory. The field was then flooded followed by plot layout, fencing, basal fertilizer application and puddling of each plot using a hand operated puddling machine.

Table 1: Soil Chemical composition of the Experimental Field (RE-3).

\begin{tabular}{|c|c|c|c|c|}
\hline $\begin{array}{l}\text { Total C } \\
\left(\mathrm{g} . \mathrm{kg}^{-1}\right) \\
\end{array}$ & $\begin{array}{l}\text { Total N } \\
\left({\left.\mathrm{g} . \mathrm{kg}^{-1}\right)}\right.\end{array}$ & $\begin{array}{c}\text { Available P (Bray2) } \\
\left(\mathrm{mg} \cdot \mathrm{kg}^{-1}\right)\end{array}$ & $\begin{array}{c}\text { Exchangeable } \mathrm{K} \\
\text { cmol (+). } \mathrm{kg}^{-1}\end{array}$ & $\begin{array}{c}\mathrm{pH} \\
\left(\mathrm{H}_{2} \mathrm{O}\right)\end{array}$ \\
\hline 13.3 & 1.18 & 68.3 & 0.310 & 6 \\
\hline
\end{tabular}

2.4. Transplanting

Rice seedlings were manually transplanted five weeks after sowing at a spacing of $30 \mathrm{~cm} \mathrm{x} 15 \mathrm{~cm}$ giving the plant density of 22.22 hills per $\mathrm{m}^{-2}$. Prior to transplanting, seedlings were treated with a systemic fungicide to prevent and combat fungal diseases that may arise during cultivation. Transplanted seedlings had a plant age in leave number of 4.2, plant length of $27.46 \mathrm{~cm}$, and leaf color of 3.5 on the Leaf Color Chart.

\subsection{Fertilizers Application}

Basal fertilization was done prior to puddling by application of uniform amount of granular fertilizers containing Nitrogen, Phosphorus and Potassium in all the plots to supplement the soil's Nitrogen, Phosphorus and Potassium respective contents. Phosphorus $\left(\mathrm{P}_{2} \mathrm{O}_{5}\right)$ was applied at the rate of $100 \mathrm{Kg} \mathrm{ha}^{-1}$ in form of Single superphosphate (SSP: $18 \%$ P205). Potassium $\left(\mathrm{K}_{2} \mathrm{O}\right)$ was applied at the rate of $80 \mathrm{Kg} \mathrm{ha}^{-1}$ at basal, and $25 \mathrm{Kg} \mathrm{ha}^{-1}$ at panicle initiation stage in form of Potassium chloride (KCl: $60 \% \mathrm{~K} 20$ ). Nitrogen was applied at the rate of $30 \mathrm{Kg} \mathrm{ha}^{-1}$ in form Ammonium Sulfate $\left(\mathrm{NH}_{4}\right)_{2} \mathrm{SO}_{4}$ $(21 \% \mathrm{~N})$.

Two different amounts of Ammonium Sulfate $\left(\mathrm{NH}_{4}\right)_{2} \mathrm{SO}_{4}$ fertilizer $\left(20 \mathrm{Kg} \mathrm{ha}^{-1}\right.$ and $\left.50 \mathrm{Kg} \mathrm{ha}^{-1}\right)$ were applied as Top dressing. Each of the two amounts was applied at three different timings namely at 14 days after transplanting (14DAT), at panicle initiation stage (PI) and at flowering stage (FL) respectively, constituting the six treatments (14DAT:20, 14DAT:50, PI:20, PI:50, FL:20 \& FL:50) (Table 2). Determination of panicle initiation stage was done in the laboratory by dissecting the stem of the plants and observing its base.

\subsection{Experimental Design}

A Randomized Complete Block Design (RCBD) with six treatments and three replications was used for this experiment. The experimental field was divided into 18 split plots, each of which had a dimension $4 \mathrm{~m} \times 3.42 \mathrm{~m}$. Table 2 below summarizes the various Nitrogen amount and application timings used in this experiment.

Table 2. Nitrogen fertilizer (Ammonium sulfate) amounts and timings.

\begin{tabular}{|c|c|c|c|c|c|}
\hline \multirow{2}{*}{ Treatment } & \multirow[t]{2}{*}{ Basal Nitrogen $\left(\mathrm{kg} \mathrm{ha}^{-1}\right)$} & \multicolumn{4}{|c|}{ Nitrogen Top dressing $\left(\mathrm{kg} \mathrm{ha}^{-1}\right)$} \\
\hline & & 14 DAT & PI & FL & Total \\
\hline 14DAT: 20 & 30 & 20 & & & 50 \\
\hline 14DAT: 50 & 30 & 50 & & & 80 \\
\hline PI: 20 & 30 & & 20 & & 50 \\
\hline PI: 50 & 30 & & 50 & & 80 \\
\hline FL: 20 & 30 & & & 20 & 50 \\
\hline FL: 50 & 30 & & & 50 & 80 \\
\hline
\end{tabular}

14 DAT $=$ Days after transplanting, $\mathbf{P I}=$ Panicle initiation stage, $\mathbf{F L}=$ Flowering stage

\subsection{Data Collection}

\section{Determination of Growth Parameters}

Growth data were collected from seven days after transplanting and continued weekly until harvest. Growth data were collected from 6 hills per plot. Three growth parameters were collected in this experiment: Plant length measured weekly using a ruler from the base of the stem (hill) to the tip of the tallest leaf; Number of tillers per hill counted and recorded manually once a week; and Leaf color determined using a Leaf Color Chart (LCC.

\section{Determination of Yield Components}

The number of panicles per square meter was determined by counting the total number of panicles and the number of sterile panicles of 10 hills at three different survey points in the sample field, and then deducting the number of sterile panicles from the total number of panicles. The value obtained after the deduction represented the number of fertile panicles. To determine the number of spikelets per panicle, we started by counting the number of spikelets of a total of 10 hills collected from three separate survey points. Three hills were collected from the first point, four hills from the second point, 
and three hills from the third point. At each survey point, the number of spikelets of the highest panicle and second lowest panicle of the hills were counted and the average number of spikelets per panicle was calculated. The number of spikelets per square meter was calculated by multiplying the number of spikelets per panicle by the number of fertile panicles per square meter. The determination of the filled grain percentage or ripening ration was obtained from the ration of number of filled grains to the total number of spikelets. To separate filled grains from unfilled grains, water of 1.0 specific gravity was used. The 1000-grains weight was obtained and adjusted to $14 \%$ moisture content.

\subsection{Data analysis}

Microsoft Excel was used for data arrangement and processing. An MS Excel based software was used for statistical analyses and analysis of variance (ANOVA). Differences among means were separated by Fisher's least significant difference (LSD) test and Tukey's HSD Least Significance Difference test at 0.05 probability level $(\mathrm{p}<0.05)$. MS Excel was used to produce tables and graphs, and all error bars to indicate standard errors of means.

\subsection{Growth Parameters \\ Plant length}

The effect of the amount and timing of a single top-dressing application of Ammonium Sulfate fertilizer on the plant length of Akitakomachi rice is shown in Table 3. Applications of 50kgha ${ }^{-1}$ of Ammonium Sulfate at 14 days after transplanting (14 DAT: 50) and at panicle initiation stage (PI: 50) significantly increased the plant length of rice compared to other treatments (Figure 1). The lowest plant lengths were observed in plants that received Ammonium Sulfate application at flowering stage; FL:20 an FL:50.

\section{Tiller number}

The number of tillers per hill as affected by the amount and timing of Ammonium Sulfate single top-dressing application is illustrated in Table 4. Ammonium Sulfate applications of both $20 \mathrm{kgha}^{-1}$ and $50 \mathrm{kgha}^{-1}$ at 14 days after transplanting (14 DAT: 20 and 14 DAT: 50) significantly increased the number of tillers per hill from transplanting to maximum tillering stage compared to the other four treatments. The highest number of tillers per hill were observed in 14 DAT: 50 (Figure 2). The lowest number of tillers per hill were observed in plants that received Ammonium Sulfate applications at flowering stage (FL: 20 and FL: 50). However, after maximum tillering stage, the tiller number of plants that received Ammonium Sulfate fertilizer at panicle initiation stage was almost like that of 14 DAT: 50, but with 14 DAT: 50 still significantly higher.

\section{Leaf color}

The leaf color of rice plants as affected by the amount and timing of a single top-dressing application with Ammonium Sulfate fertilizer is shown in Table 5. Each of the six treatments significantly increased the leaf color of the plants for more than seven days after each application. However, although the leaf color was significantly increased after each application, the leaf color decreased from the second week after the application in all the six treatments. (Figure 3).

\subsection{Yield components}

The data presented in Table 6 show the yield components of Akitakomachi rice in response to different amounts and timings of a single top-dressing application of Ammonium Sulfate fertilizer.

\section{Number of Panicles per square meter}

14 DAT: 50 and PI: 50 significantly increased the number of panicles per $\mathrm{m}^{2}$ compared to other treatments and the highest number of panicles per $\mathrm{m}^{2}$ were observed in 14 DAT: 50 . Also, the number of panicles per $\mathrm{m}^{2}$ were significantly higher in all plants treated with 50kgha ${ }^{-1}$ Ammonium Sulfate (14 DAT: 50, PI: 50 and FL: 50) compared to those treated with 20kgha ${ }^{-1}$ (14 DAT: 20, PI: 20 and FL: 20) (Figure 4).

\section{Number of spikelets per panicle.}

PI: 20 and PI: 50 significantly increased the number of spikelets per panicle compared to the other treatments (Figure 5). The lowest number of spikelets per panicle were observed in FL: 50, and there was no significant difference between 14 DAT: 20, 14 DAT: 50 and FL: 20.

\section{Spikelet fertility}

Although the spikelet fertility rates of 14 DAT: 20, 14 DAT: 50 and FL: 50 appeared to be slightly higher than those of the other treatments, there was no significant difference among all the six treatments at 0.05 probability level.(Figure 6).

\section{0 grain weight}

The 1000 grain weight at $14 \%$ moisture content was significantly higher in PI: 50 compared to other treatments (Figure 7). The lowest 1000 grain weights were observed in 14 DAT: 50 and FL: 20 but there was no significant difference among the two treatments. 


\section{Calculated yield}

14 DAT: 50 and PI: 50 significantly increased the calculated yield compared to other treatments (Figure 8). Both applications of Ammonium Sulfate at 14 days after transplanting (14 DAT: 20 and 14 DAT: 50) showed significantly higher calculated yields compare to PI: 20. The lowest calculated yields were observed in plants that received Ammonium Sulfate application at flowering stage (FL: 20 and FL: 50).

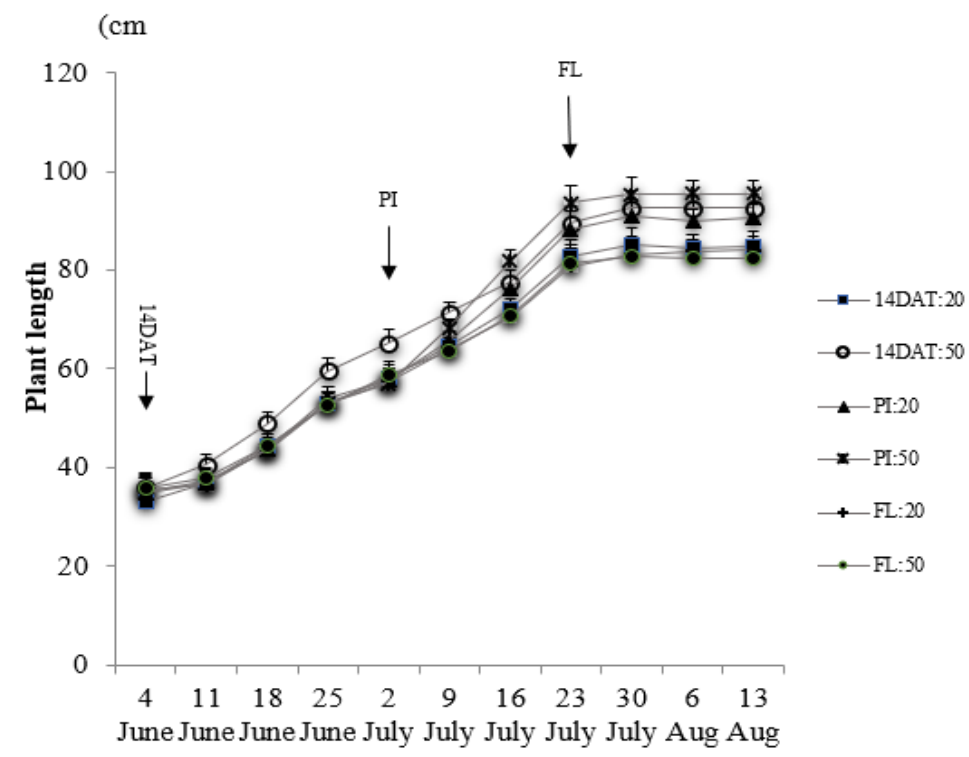

Figure 1. Plant length of Akitakomachi rice as influenced by ammonium sulfate fertilizer amount and application timing from June $4^{\text {th }}$ to august $13^{\text {th }}$. Error bars above means presents standard error of three replicates. 14DAT:20 $=20 \mathrm{~kg} \cdot \mathrm{ha}^{-1}$ of $(\mathrm{NH} 4)_{2} \mathrm{SO}_{4}$ at 14 days after transplanting, $14 \mathrm{DAT}: 50=50 \mathrm{~kg} \cdot \mathrm{ha}^{-1}$ of $(\mathrm{NH} 4)_{2} \mathrm{SO}_{4}$ at 14 days after transplanting, PI:20 $=20 \mathrm{~kg} \cdot \mathrm{ha}^{-1}(\mathrm{NH} 4)_{2} \mathrm{SO}_{4}$ at panicle initiation stage, PI:50 $=50 \mathrm{~kg}^{-h a}{ }^{-1}(\mathrm{NH} 4)_{2} \mathrm{SO}_{4}$ at panicle initiation stage FL:20 $=20 \mathrm{~kg} \cdot \mathrm{ha}^{-1}(\mathrm{NH} 4)_{2} \mathrm{SO}_{4}$ at flowering stage and FL:50 $=50 \mathrm{~kg} \cdot \mathrm{ha}^{-1}(\mathrm{NH} 4)_{2} \mathrm{SO}_{4}$ at flowering stage.

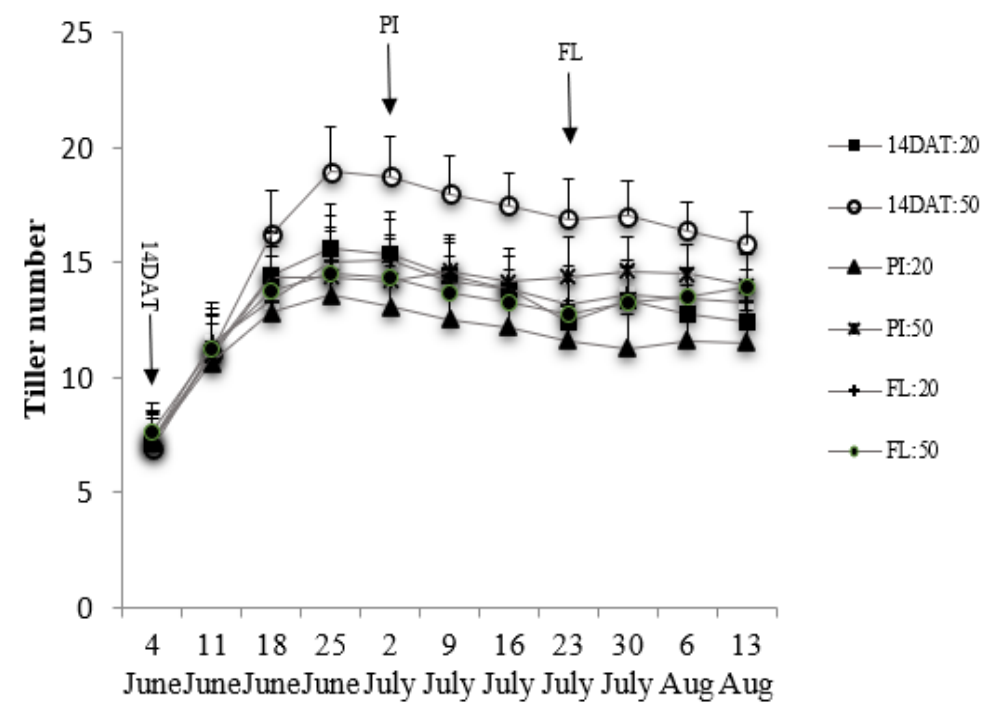

Figure 2: Tiller number of Akitakomachi rice as influenced by ammonium sulfate fertilizer amount and application timing. Error bars above means presents standard error of three replicates. 


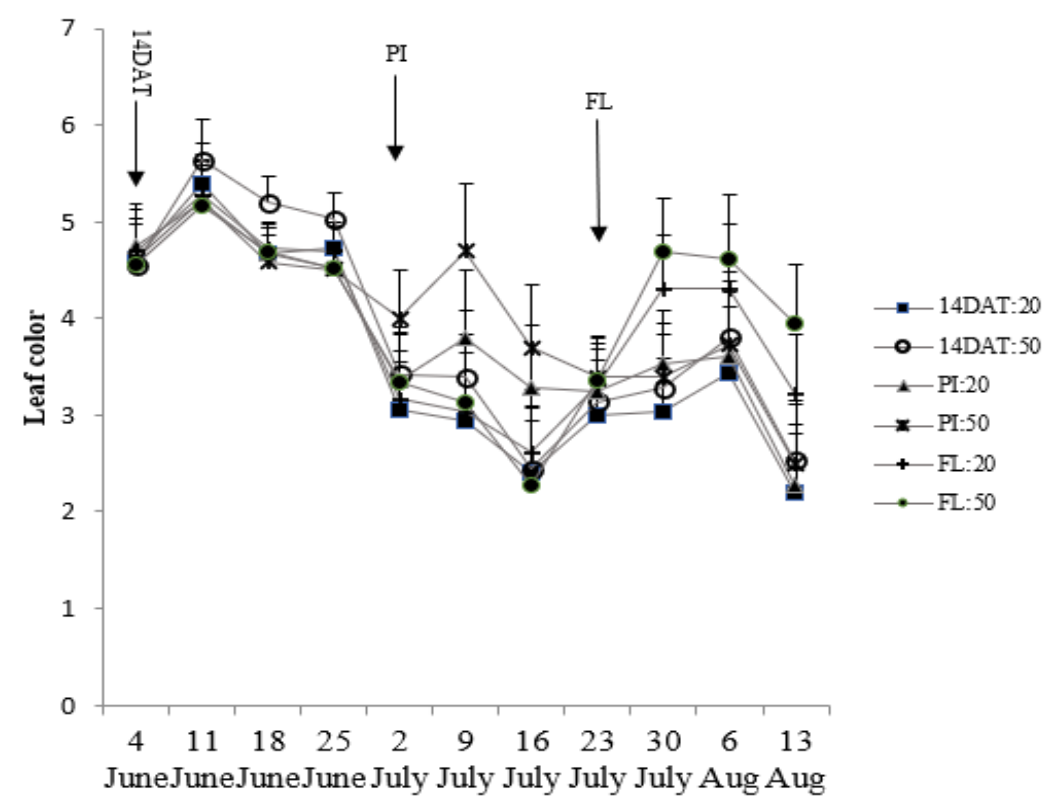

Figure 3. Leaf Color of rice as influenced by ammonium sulfate fertilizer amount and application timing. Error bars above means presents standard error of three replicates. 
Table 3. Plant length of Akitakomachi rice as influenced by Ammonium sulfate fertilizer amounts and application timing.

\begin{tabular}{rrrrrrrrrrrr}
\hline & 14 DAT & 21 DAT & 28 DAT & 35 DAT & PI & 49 DAT & 56 DAT & FL & 70 DAT & 77 DAT & 84 DAT \\
\hline 14DAT:20 & $33.16 \mathrm{a}$ & $36.69 \mathrm{~b}$ & $44.46 \mathrm{~b}$ & $52.92 \mathrm{~b}$ & $58.09 \mathrm{~b}$ & $64.43 \mathrm{c}$ & $71.93 \mathrm{c}$ & $82.67 \mathrm{~b}$ & $84.98 \mathrm{~b}$ & $84.51 \mathrm{c}$ & $84.93 \mathrm{c}$ \\
\hline 14DAT:50 & $35.92 \mathrm{a}$ & $40.54 \mathrm{a}$ & $48.95 \mathrm{a}$ & $59.53 \mathrm{a}$ & $65.13 \mathrm{a}$ & $71.39 \mathrm{a}$ & $77.51 \mathrm{~b}$ & $89.42 \mathrm{a}$ & $92.57 \mathrm{a}$ & $92.6 \mathrm{ab}$ & $92.52 \mathrm{ab}$ \\
\hline PI:20 & $34.9 \mathrm{a}$ & $36.69 \mathrm{~b}$ & $43.84 \mathrm{~b}$ & $53.86 \mathrm{~b}$ & $57.57 \mathrm{~b}$ & $65.64 \mathrm{bc}$ & $76.32 \mathrm{~b}$ & $88.31 \mathrm{a}$ & $90.77 \mathrm{a}$ & $89.83 \mathrm{~b}$ & $90.5 \mathrm{~b}$ \\
\hline PI:50 & $35 \mathrm{a}$ & $37.14 \mathrm{ab}$ & $43.35 \mathrm{~b}$ & $52.94 \mathrm{~b}$ & $57 \mathrm{~b}$ & $68.24 \mathrm{~b}$ & $81.8 \mathrm{a}$ & $93.51 \mathrm{a}$ & $95.32 \mathrm{a}$ & $95.53 \mathrm{a}$ & $95.47 \mathrm{a}$ \\
\hline FL:20 & $35.46 \mathrm{a}$ & $36.46 \mathrm{~b}$ & $43.62 \mathrm{~b}$ & $52.77 \mathrm{~b}$ & $57.52 \mathrm{~b}$ & $63.77 \mathrm{c}$ & $70.46 \mathrm{c}$ & $80.77 \mathrm{~b}$ & $83.11 \mathrm{~b}$ & $83.77 \mathrm{c}$ & $83.98 \mathrm{c}$ \\
\hline FL:50 & $35.67 \mathrm{a}$ & $37.7 \mathrm{ab}$ & $44.39 \mathrm{~b}$ & $52.49 \mathrm{~b}$ & $58.73 \mathrm{~b}$ & $63.59 \mathrm{c}$ & $70.78 \mathrm{c}$ & $81.49 \mathrm{~b}$ & $82.59 \mathrm{~b}$ & $82.48 \mathrm{c}$ & $82.42 \mathrm{c}$
\end{tabular}

Values in the table are means of three replications. Within a column, means with the same letter do not differ significantly at 0.05 probability level. $14 \mathrm{DAT}: 20=20 \mathrm{~kg}$. ha ${ }^{-1}$ of $(\mathrm{NH} 4)_{2} \mathrm{SO}_{4}$ at 14 days after transplanting, $14 \mathrm{DAT}: 50=50 \mathrm{~kg}^{-h{ }^{-1}}$ of $(\mathrm{NH} 4)_{2} \mathrm{SO}_{4}$ at 14 days after transplanting, PI:20=20kg.ha ${ }^{-1}(\mathrm{NH} 4)_{2} \mathrm{SO}{ }_{4}$ at panicle initiation stage, PI:50 $=50 \mathrm{~kg} \cdot \mathrm{ha}^{-1}(\mathrm{NH} 4)_{2} \mathrm{SO}_{4}$ at panicle initiation stage $\mathrm{FL}: 20=20 \mathrm{~kg} \cdot \mathrm{ha}^{-1}(\mathrm{NH} 4)_{2} \mathrm{SO}_{4}$ at flowering stage and FL:50 = 50kg.ha-1 $\left(\mathrm{NH}_{4}\right)_{2} \mathrm{SO} 4$ at flowering stage.

Table 4. Number of tillers per hill of Akitakomachi rice as influenced by Ammonium sulfate fertilizer amounts and application timing.

\begin{tabular}{|c|c|c|c|c|c|c|c|c|c|c|c|}
\hline & 14 DAT & 21 DAT & 28 DAT & 35 DAT & PI & 49 DAT & 56 DAT & FL & 70 DAT & 77 DAT & 84 DAT \\
\hline 14DAT:20 & $7.11 \mathrm{a}$ & $11.06 \mathrm{a}$ & $14.44 \mathrm{ab}$ & $15.61 \mathrm{~b}$ & $15.39 \mathrm{~b}$ & $14.44 \mathrm{~b}$ & $13.83 \mathrm{~b}$ & $12.44 \mathrm{bc}$ & $13.33 \mathrm{bc}$ & $12.72 \mathrm{bc}$ & $12.39 \mathrm{bc}$ \\
\hline 14DAT:50 & $6.89 \mathrm{a}$ & $11.06 \mathrm{a}$ & $16.22 \mathrm{a}$ & $18.94 \mathrm{a}$ & $18.72 \mathrm{a}$ & $18 \mathrm{a}$ & $17.5 \mathrm{a}$ & $16.89 \mathrm{a}$ & $17 \mathrm{a}$ & $16.39 \mathrm{a}$ & $15.78 \mathrm{a}$ \\
\hline PI:20 & $7.22 \mathrm{a}$ & $10.61 \mathrm{a}$ & $12.83 \mathrm{~b}$ & $13.56 \mathrm{~b}$ & $13.06 \mathrm{~b}$ & $12.5 \mathrm{~b}$ & $12.17 \mathrm{~b}$ & $11.61 \mathrm{c}$ & $11.28 \mathrm{c}$ & $11.61 \mathrm{c}$ & $11.5 \mathrm{c}$ \\
\hline PI:50 & $7.28 \mathrm{a}$ & $10.94 \mathrm{a}$ & $14.33 \mathrm{ab}$ & $14.39 \mathrm{~b}$ & $14.22 \mathrm{~b}$ & $14.61 \mathrm{~b}$ & $14.17 \mathrm{~b}$ & $14.39 \mathrm{ab}$ & $14.61 \mathrm{~b}$ & $14.5 \mathrm{ab}$ & $14 \mathrm{ab}$ \\
\hline FL:20 & $7.17 \mathrm{a}$ & $11.5 \mathrm{a}$ & $13.33 \mathrm{ab}$ & $15.06 \mathrm{~b}$ & $15.11 \mathrm{~b}$ & $14.22 \mathrm{~b}$ & $13.83 \mathrm{~b}$ & $13.14 \mathrm{bc}$ & $13.61 \mathrm{bc}$ & $13.44 \mathrm{bc}$ & $13.28 \mathrm{bc}$ \\
\hline FL:50 & $7.61 \mathrm{a}$ & $11.28 \mathrm{a}$ & $13.72 \mathrm{ab}$ & $14.56 \mathrm{~b}$ & $14.39 \mathrm{~b}$ & $13.67 \mathrm{~b}$ & $13.28 \mathrm{~b}$ & $12.72 \mathrm{bc}$ & $13.22 \mathrm{bc}$ & $13.5 \mathrm{bc}$ & $13.94 \mathrm{ab}$ \\
\hline
\end{tabular}

Within a column, means with the same letter do not differ significantly at 0.05 probability level. 
Table 5. Leaf color of Akitakomachi rice as influenced by Ammonium sulfate fertilizer amounts and application timing.

\begin{tabular}{rrrrrrrrrrrr}
\hline & 14 DAT & 21 DAT & 28 DAT & 35 DAT & PI & 49 DAT & 56 DAT & FL & 70 DAT & 77 DAT & 84 DAT \\
\hline 14DAT:20 & $4.61 \mathrm{a}$ & $5.39 \mathrm{a}$ & $4.67 \mathrm{~b}$ & $4.72 \mathrm{ab}$ & $3.06 \mathrm{~b}$ & $2.94 \mathrm{~b}$ & $2.42 \mathrm{~b}$ & $3 \mathrm{a}$ & $3.028 \mathrm{c}$ & $3.44 \mathrm{~b}$ & $2.19 \mathrm{c}$ \\
\hline 14DAT:50 & $4.56 \mathrm{a}$ & $5.64 \mathrm{a}$ & $5.19 \mathrm{a}$ & $5.03 \mathrm{a}$ & $3.42 \mathrm{ab}$ & $3.39 \mathrm{~b}$ & $2.44 \mathrm{~b}$ & $3.14 \mathrm{a}$ & $3.28 \mathrm{c}$ & $3.81 \mathrm{ab}$ & $2.53 \mathrm{bc}$ \\
\hline PI:20 & $4.75 \mathrm{a}$ & $5.19 \mathrm{a}$ & $4.67 \mathrm{~b}$ & $4.53 \mathrm{~b}$ & $3.36 \mathrm{ab}$ & $3.81 \mathrm{ab}$ & $3.28 \mathrm{ab}$ & $3.25 \mathrm{a}$ & $3.53 \mathrm{bc}$ & $3.61 \mathrm{ab}$ & $2.28 \mathrm{bc}$ \\
\hline PI:50 & $4.61 \mathrm{a}$ & $5.22 \mathrm{a}$ & $4.58 \mathrm{~b}$ & $4.50 \mathrm{~b}$ & $4 \mathrm{a}$ & $4.69 \mathrm{a}$ & $3.69 \mathrm{a}$ & $3.39 \mathrm{a}$ & $3.39 \mathrm{c}$ & $3.72 \mathrm{ab}$ & $2.50 \mathrm{bc}$ \\
\hline FL:20 & $4.69 \mathrm{a}$ & $5.28 \mathrm{a}$ & $4.72 \mathrm{~b}$ & $4.69 \mathrm{ab}$ & $3.17 \mathrm{~b}$ & $3.03 \mathrm{~b}$ & $2.61 \mathrm{~b}$ & $3.31 \mathrm{a}$ & $4.31 \mathrm{ab}$ & $4.31 \mathrm{ab}$ & $3.22 \mathrm{ab}$ \\
\hline FL:50 & $4.56 \mathrm{a}$ & $5.17 \mathrm{a}$ & $4.69 \mathrm{~b}$ & $4.53 \mathrm{~b}$ & $3.33 \mathrm{ab}$ & $3.14 \mathrm{~b}$ & $2.28 \mathrm{~b}$ & $3.36 \mathrm{a}$ & $4.69 \mathrm{a}$ & $4.61 \mathrm{a}$ & $3.94 \mathrm{a}$ \\
\hline
\end{tabular}

Within a column, means with the same letter do not differ significantly at 0.05 probability level.

\begin{tabular}{lllll}
\hline & $\begin{array}{l}\text { No. of Panicles } \\
\text { /m2 }\end{array}$ & $\begin{array}{l}\text { No. of Spikelet/ } \\
\text { panicle }\end{array}$ & Spikelet fertility (\%) & $\begin{array}{l}\text { 1000 grain weight(g) } \\
\text { at 14\% }\end{array}$ \\
\hline Moist.
\end{tabular}

Table 6. Yield and yield components of Akitakomachi rice as influenced by Ammonium sulfate fertilizer amount and application timing.

Values in the table are means of three replications. Within a column, values with the same letter do not differ significantly at 0.05 probability level. 


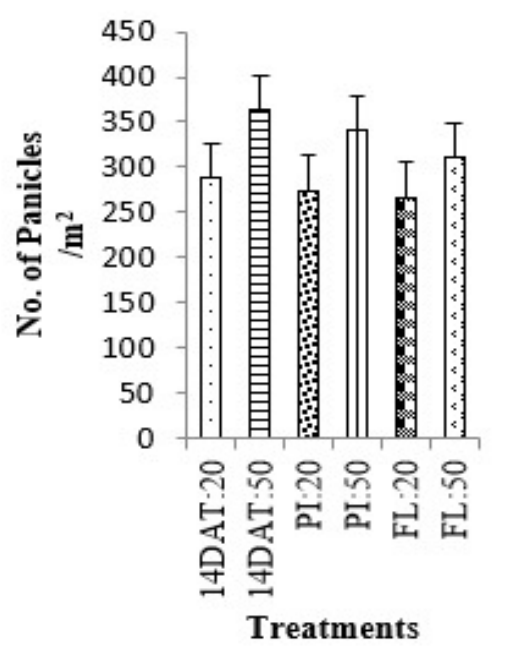

Figure 4. Number of panicles per $\mathrm{m}^{2}$.

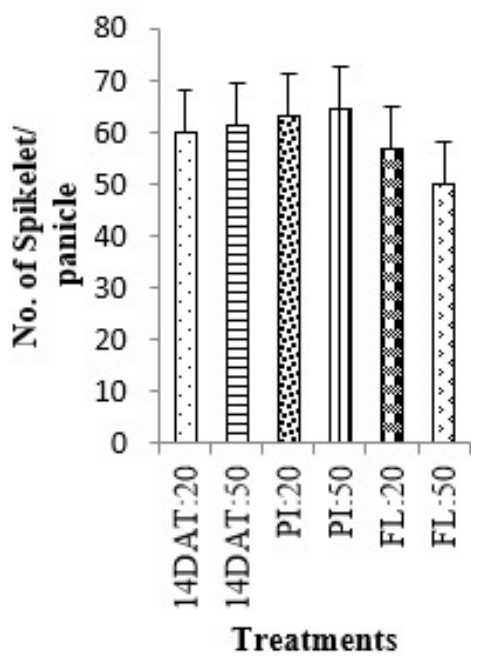

Figure 5. Number of spikelets per panicle.

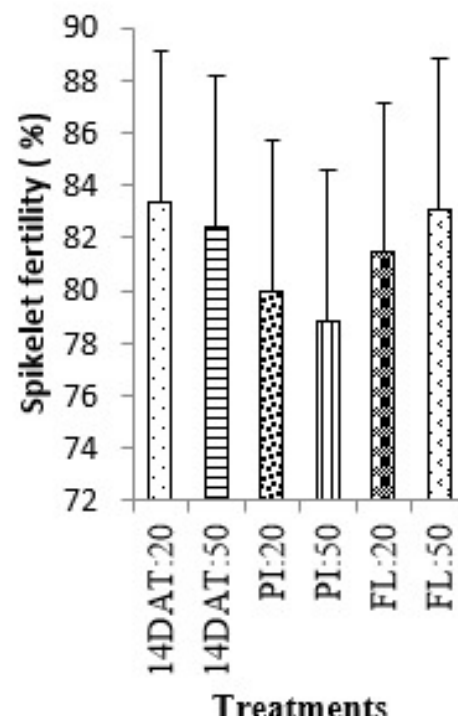

Figure 6. Spikelet fertility.

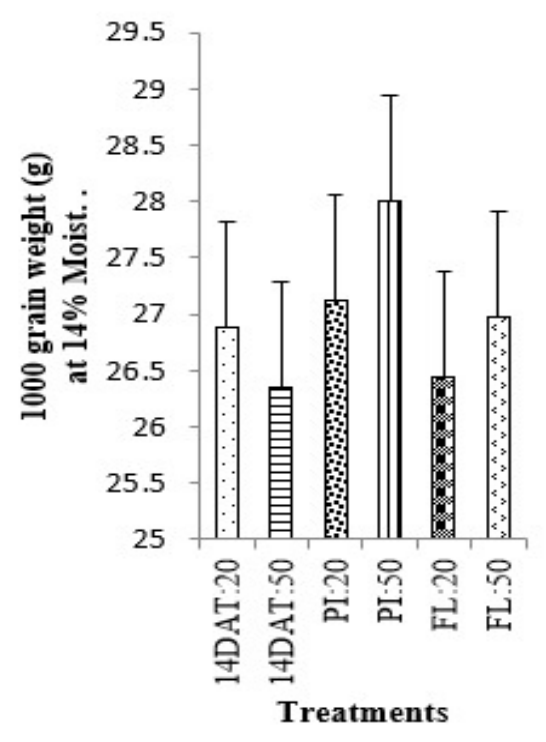

Figure 7. 1000 grains weight.

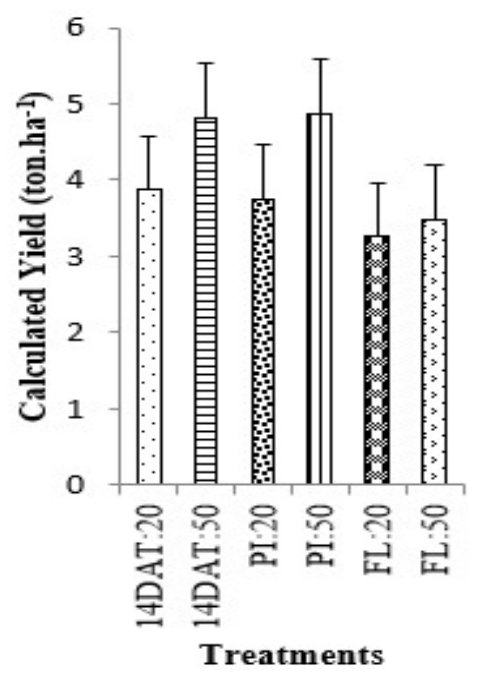

Figure 8. Calculated yield.

Figures 4, 5, 6, 7 and 8 show the number of panicles per m2, number of spikelets per panicle, spikelet fertility, 1000 grains weight, and the calculated yield of rice as influenced by Ammonium sulfate fertilizer amount and application timing respectively .

\subsection{Growth parameters \\ Plant length}

We found that application of high amount of Ammonium Sulfate fertilizer as single top-dressing at the start of tillering (vegetative stage) or at panicle initiation stage (start of reproductive stage), significantly increased the plant length of Akitakomachi rice (Figure 1). This result was consistent with the findings of Li et al., (2013) who concluded that increased amounts of nitrogen input significantly increased the plant length and basal internode length or rice. The increase in plant length that resulted from the application of high amount of nitrogen fertilizer at vegetative stage or at panicle initiation stage was because nitrogen is considered the most important component for supporting plant growth. Nitrogen has been reported to play a key role in plant development as it is involved in the production of chlorophyll, which is crucial 
for photosynthesis (Munoz-Huerta et al.,2013). Nitrogen is also known to be the primary building block for plant protoplasm, which enhances speedy shoot growth. Previous studies have reported that, nitrogen promotes plant growth and increases the number of internodes and the length of internodes, thus an increase in nitrogen fertilizer application increases the plant length (Gasim, 2001). Although high amounts of nitrogen fertilizer were applied at flowering stage, the plant length was significantly lower compared to other treatments. A possible explanation could be the fact that, after heading stage, the activity of the roots decreases in the soil. Also, it is likely that after heading, most of the nutrients absorbed by the plant are used more for grain filling and less for plant growth. However, although high amount of nitrogen fertilizer increased plant length, higher amounts of nitrogen fertilizer application could make the plants to lodge. Numerous studies have reported that there is a significant correlation between lodging and plant length (UNAN et al., 2013). Some previous studies have reported that taller plants may have higher yields, but they may also have a high risk of lodging (Xue et al., 2019). Other studies have concluded that a taller rice plant is more susceptible to lodging and has a poor response to nitrogen (Yoshida, 1978).

\section{Tiller number}

We found that both amounts of Ammonium sulfate application at 14 days after transplanting (14 DAT: 20 and 14 DAT: 50) had the highest number of tillers per hill (Figure 2). This result was consistent with several previous findings which concluded that applying nitrogen during the vegetative stage of rice growth increased the number of tillers. It has been reported that rice farmers in china apply 56-85\% of the season's total nitrogen at tillering stage (Sui et al., 2013), because high amounts of nitrogen fertilizers increase tiller number of rice (Yosef, 2012). Previous studies also reported that nitrogen application during vegetative stage of rice promotes its growth and tillering (Tayefe et al., 2014). The increase in the number of tillers due to nitrogen application at vegetative stage can be explained by the fact that, nitrogen $(\mathrm{N})$ is needed to produce chlorophyll which is crucial for photosynthesis (Munoz-Huerta et al.,2013), and during the period of tillering, Nitrogen demands are reported to be greatest (Peng et Cassman, 1998). It was reported that, applying nitrogen at tillering stage augment root activity, which is especially important during rice tillering for the absorption of nutrients and water (Baral et al., 2020). Studies have also shown that rice plant requires nitrogen during vegetative stage to promote growth and tillering (Tayefe et al.,2014). Furthermore, some previous studies have confirmed that nitrogen top-dressing at 7-14 days after transplanting promotes tillering (Ye et al., 2019). However, although nitrogen application at 14 days after transplanting increased tiller number, higher quantities of nitrogen fertilizer may enhance the production of non-productive tillers. It has been reported that increased amounts of nitrogen promoted tiller heterogeneity in rice (Wang et al., 2016). Meanwhile, the number of productive tillers per plant is one of the most important agronomic traits associated with the grain yields of rice crops (Deng et al., 2020). Some studies have shown that by reducing the amount of nitrogen input at basal application, the number of non-productive tillers could be significantly decreased (Zeng et al., 2012).

\section{Leaf color}

After each nitrogen $(\mathrm{N})$ fertilizer application, the leaf color of the plants significantly increased in all the treatments (Figure 3). Previous studies have shown that there is a significant positive correlation between the leaf color and the nitrogen content (Tao et al.,2020) and that the evaluation of nitrogen status by leaf color is a classical method to diagnose plants nutritional status (Hou et al., 2020). The increase in leaf color observed after each nitrogen fertilizer application, and its decrease few days later could be explained by the fact that, nitrogen fertilizer applications increased the amount of available nitrogen in the soil which plants absorbed immediately. Also, the nitrogen (N) contained in chemical fertilizers is in an inorganic form, which makes it immediately absorbable by plants, but its content in the soil decreases rapidly with time. Previous studies have reported that 10 to $60 \%$ of the nitrogen derived from chemical fertilizers applications is lost in the soil (Vlek \& Byrnes, 1986; De Datta \& Buresh, 1989), and only a small portion is used by the plant. Furthermore, nitrogen use efficiency (NUE) in rice plant is reported to be extremely low as the plants use only a very little amount (20-30\%) of the nitrogen fertilizer applied (Peng et al., 2006). Some studies have reported that nitrogen uptake and utilization by rice plant varies between growth stages (Yang et al., 2007). Although in this study the nitrogen uptake capacity at various growth stages was not evaluated, the plants responded positively to nitrogen fertilizer applications and the leaf color increased significantly at each growth stage including at flowering stage.

\section{Yield components}

We found that during a single top-dressing application of nitrogen fertilizer, high amounts $\left(50 \mathrm{~kg} \cdot \mathrm{ha}^{-1}\right) \mathrm{produced}$ significantly higher number of panicles per $\mathrm{m}^{2}$ compared to low amounts $\left(20 \mathrm{~kg}^{-h^{-1}}\right)$ (Figure 4$)$. The possible reason for this could be that plants treated with high amounts of Ammonium sulfate produced more tillers than those that were treated with low amount. This result was consistent with the findings of Liang et al., (2014) who had previously reported that the more a rice plant could produce tillers, the higher its panicle number. Liao et al., (2019) also reported that, the tiller number per plant determines the panicle number. The highest number of panicles per $\mathrm{m}^{2}$ that was observed in 14 DAT:50 could thus be justified by the fact that 14DAT: 50 was the treatment that produced the highest number of tillers. We also found that single top-dressing application of Ammonium sulfate at panicle initiation stages (PI:20 and PI:50) produced a significantly higher number of spikelets per panicle compared to other treatments. This result was consistent with numerous previous studies that confirmed that nitrogen top-dressing at panicle initiation stage was the best timing to increase the number of spikelets per panicle. It was previously reported that nitrogen top-dressing at panicle initiation stage is an effective and necessary practice to enhance the number of spikelets produced in rice (Kamiji et al., 2011; Sui et al., 2013; 
Ding \& Maruyama, 2004). Similarly, it was concluded that the most effective timing for nitrogen application to increase spikelet number per panicle was at the panicle initiation stage (Brinkhoff et al.,2019).

Furthermore, we found that nitrogen top-dressing amounts and timings did not show any significant differences in terms of spikelets fertility, even though PI:20 and PI:50 had lower values (Figure 6). These results were consistent with the findings of Yang et al., (2002), Wang et al., (2006) and Islam et at., (2010) who reported that the more there are spikelets on a panicle, the lower the spikelet fertility percentage could be. Thus, we expected the spikelet fertility of PI:20 and PI:50 to be significantly lower because they had the highest number of spikelets per panicles. However, other studies suggested that applying nitrogen fertilizer at panicle initiation stage increases the fertility rate of the spikelets because nitrogen improves photosynthetic capacity and promotes carbohydrates accumulation (Mae, 1997).

Our results also showed that 14 DAT:50 and PI:50 produced significantly higher yields compared to the other treatments (Figure 8). The possible reason was that these two treatments produced the highest number of panicles per $\mathrm{m}^{2}$. This result is also consistent with previous studies that concluded that the main factor that determines rice yield is the number of panicles per $\mathrm{m}^{2}$. Other studies have suggested that, the most important component of yield in rice plant is the number of panicle and that it accounts for $87 \%$ of the yield variation (Fageria \& Baligar, 1999). Patrick and collaborators, (1974) reported that nitrogen fertilizer application at panicle initiation stage increases protein content and grain yield of rice. This important role of the number of panicles was also confirmed by Kamiji et al., 2011 and Sui et al., 2013, who reported that high yield of rice could be obtained by enhancing the production of rice spikelet through application of nitrogen top-dressing at panicle initiation stage. 14 DAT:20 and 14DAT:50 had significantly higher yield compared to PI:20. These results suggested that, with little amount of nitrogen available for top-dressing, applying it during the vegetative stage and maximizing on the number of tillers could be more efficient than applying it at panicle initiation stage.

We found that, under normal adequate weather conditions, single nitrogen top dressing application at flowering had a significantly lower yield compared to other treatments. Meanwhile, although most studies have reported higher yield with nitrogen application at panicle initiation stage, there are some studies that have suggested that nitrogen application at flowering stage could increase the rice yield under certain environmental conditions. Some of these studies reported that increased amounts of nitrogen application at panicle initiation or at flowering could alleviated the detrimental effects of high temperature on yield (Dai et al., 2009; Duan et al.,2013; Yang et al. 2014). Our findings were also inconsistent with some studies that reported that application of nitrogen fertilizer at flowering stage increased rough rice yield and resulted in high quantity of head-milled rice content (Consuelo et al.,1996). Furthermore, it was reported that, high amount of nitrogen fertilizer top-dressing at flowering stage could increase the yield of rice (Cassman et al., 1993, 1994). Nitrogen application at flowering resulted in a 30-60 \% increase in head rice protein yield (Consuelo et al.,1996), suggesting that nitrogen fertilizer applications at flowering stage could play a key role in determining the rice quality by increasing the quantity of head-rice and by increasing total protein content.

\subsection{Conclusion}

Nitrogen Amount and Timing are key factors in rice cultivation. Paddy grain yield is higher when nitrogen topdressing is done with high nitrogen amount than with low nitrogen amount. However, for this high amount of nitrogen to be effective, it must be applied either at early stage of plant growth (14DAT) to increase the number of tillers and panicles per hill, or at the beginning of the reproductive stage (panicle initiation stage) to increase the number of spikelets per panicle and the weight of the grains. Although the paddy yield is almost same for these two timings, the best yield components are obtained when topdressing is done at panicle initiation stage. Nevertheless, in a situation of low or little amount of nitrogen available for topdressing, it is better to apply it 14 days after transplanting because the yield is higher than if it is applied at panicle initiation stage.

\section{ACKNOWLEDGEMENT}

Japan International Cooperation Agency (JICA)

Ministry of Scientific Research and Innovation (MINRESI) Cameroon.

Institute of Agricultural Research for Development (IRAD)

Mr. WATANABE Tetsu, Mr. MARUYAMA Jumpei and NISHIOKA Miki

Professor KENJI IRIE

\section{REFERENCES}

Ågren, G. I. (1985). Theory for growth of plants derived from the nitrogen productivity concept. Physiologia plantarum, 64(1), 17-28. https://doi.org/10.1111/j.1399-3054.1985.tb01207.x

Alcantara, J. M., Cassman, K. G., Consuelo, M. P., Bienvenido, O. J., \& Samuel, P. L. (1996). Effects of late nitrogen fertilizer application on head rice yield, protein content, and grain quality of rice. Cereal Chem, 73(5), 556-560. https://agris.fao.org/agris-search/search.do?recordID=US9703984 
Baral, B. R., Pande, K. R., Gaihre, Y. K., Baral, K. R., Sah, S. K., Thapa, Y. B., \& Singh, U. (2020). Increasing nitrogen use efficiency in rice through fertilizer application method under rainfed drought conditions in Nepal. Nutrient Cycling in Agroecosystems, 118(1), 103-114. https://doi.org/10.1007/s10705-020-10086-6

Brinkhoff, J., Dunn, B. W., Robson, A. J., Dunn, T. S., \& Dehaan, R. L. (2019). Modeling mid-season rice nitrogen uptake using multispectral satellite data. Remote Sensing, 11(15), 1837. https://doi.org/10.3390/rs11151837

Cassman, K. G., Dobermann, A., \& Walters, D. T. (2002). Agroecosystems, nitrogen-use efficiency, and nitrogen management. AMBIO: A Journal of the Human Environment, 31(2), 132-140. https://doi.org./10.1579/0044-744731.2.132 Cassman, K. G., Kropff, M. J., \& Yan, Z. D. (1994). A conceptual framework for nitrogen management of irrigated rice in high-yield environments. Hybrid rice technology: New developments and future prospects, 81-96. https://ci.nii.ac.jp/naid/10017994242/

Cassman, K. G., Kropff, M. J., Gaunt, J., \& Peng, S. (1993). Nitrogen use efficiency of rice reconsidered: What are the key constraints?. In Plant nutrition-from genetic engineering to field practice (pp. 471-474). Springer, Dordrecht. www.jstor.org/stable/42939335. Accessed 25 Apr. 2021.

De Datta, S. K., \& Buresh, R. J. (1989). Integrated nitrogen management in irrigated rice. In Advances in soil science (pp. 143-169). Springer, New York, NY. https://link.springer.com/chapter/10.1007/978-1-4613-8847-0_4

Deng, R., Jiang, Y., Tao, M., Huang, X., Bangura, K., Liu, C., ... \& Qi, L. (2020). Deep learning-based automatic detection of productive tillers in rice. Computers and Electronics in Agriculture, 177, 105703. https://doi.org/10.1016/j.compag.2020.105703

Ding, Y., \& Maruyama, S. (2004). Proteins and Carbohydrates in Developing Rice Panicles with Different Numbers of Spikelets:Cultivar difference and the effect of nitrogen topdressing-. Plant production science, 7(1), 16-21. https://doi.org/10.1626/pps.7.16

Ding, Y., Wang, Q., Li, G., Liu, Z., \& Wang, S. (2009). Effect of high day-time temperature on rice quality under different panicle nitrogen treatments. Plant Nutrition and Fertilizer Science, 15(2), $276-282$. https://www.cabdirect.org/cabdirect/abstract/20093165852

Duan, H., Fu, L., Ju, C., Liu, L., \& Yang, J. (2013). Effects of application of nitrogen as panicle-promoting fertilizer on seed setting and grain quality of rice under high temperature stress. Chinese Journal of Rice Science, 27(6), 591602. https://doi.org/10.3969/j.issn.1001-7216.2013.06.005

Fageria, N. K., \& Baligar, V. C. (1999). Yield and yield components of lowland rice as influenced by timing of nitrogen fertilization. Journal of Plant Nutrition, 22(1), 23-32. https://doi.org/10.1080/01904169909365603

FAOSTAT, (2008). FAO statistical databases. Available online at htt://faostat.fao.org/site/342/ default. aspx. Accessed January 2013.

Gasim, S. H. (2001). Effect of nitrogen, phosphorus and seed rate on growth, yield and quality of forage maize (Zea mays L.). Unpublished master thesis), University of Khartoum, Sudan.

Gong, P., Liang, L., \& Zhang, Q. (2011). China must reduce fertilizer use too. Nature, 473(7347), $284-285$. https://doi.org/10.1038/473284e

Gregersen, P. L., Holm, P. B., \& Krupinska, K. (2008). Leaf senescence and nutrient remobilisation in barley and wheat. Plant Biology, 10, 37-49. https://doi.org/10.1111/j.1438-8677.2008.00114.x

Guo, J. H., Liu, X. J., Zhang, Y., Shen, J. L., Han, W. X., Zhang, W. F., ... \& Zhang, F. S. (2010). Significant acidification in major Chinese croplands. science, 327(5968), 1008-1010. https://doi.org/10.1126/science.1182570

Hou, W., Tränkner, M., Lu, J., Yan, J., Huang, S., Ren, T., ... \& Li, X. (2020). Diagnosis of nitrogen nutrition in rice leaves influenced by potassium levels. Frontiers in plant science, 11. https://doi.org/10.3389/fpls.2020.00165

Huang, J. B., Fan, X. H., Zhang, S. L., Ge, G. F., Sun, Y. H., \& Feng, X. (2007). Investigation on the economicallyecologically appropriate amount of nitrogen fertilizer applied in rice production in Fe-leaching-Stagnic Anthrosols of the Taihu Lake region. Acta Ecologica Sinica, 27(2), 588-595. (in Chinese with English abstract)

Islam, M. S., Peng, S., Visperas, R. M., Bhuiya, M. S. U., Hossain, S. A., \& Julfiquar, A. W. (2010). Comparative study on yield and yield attributes of hybrid, inbred, and NPT rice genotypes in a tropical irrigated ecosystem. Bangladesh Journal of Agricultural Research, 35(2), 343-353. DOI: https://doi.org/10.3329/bjar.v35i2.5897 
Ju, C., Buresh, R. J., Wang, Z., Zhang, H., Liu, L., Yang, J., \& Zhang, J. (2015). Root and shoot traits for rice varieties with higher grain yield and higher nitrogen use efficiency at lower nitrogen rates application. Field Crops Research, 175, 47-55. https://doi.org/10.1016/j.fcr.2015.02.007

Ju, X. T., Xing, G. X., Chen, X. P., Zhang, S. L., Zhang, L. J., Liu, X. J., ... \& Zhang, F. S. (2009). Reducing environmental risk by improving $\mathrm{N}$ management in intensive Chinese agricultural systems. Proceedings of the National Academy of Sciences, 106(9), 3041-3046. https://doi.org/10.1073/pnas.0813417106

Juan, Y., Chaohu, A. C., Qirong, S., Bin, Y., \& Xinjun, W. (2009). Fertilizer-n uptake and distribution in rice plants using \{ sup 15\} N tracer technique. Acta Agriculturae Nucleatae Sinica, 23. https://www.osti.gov/etdeweb/biblio/21480754

Kamiji, Y., Yoshida, H., Palta, J. A., Sakuratani, T., \& Shiraiwa, T. (2011). N applications that increase plant N during panicle development are highly effective in increasing spikelet number in rice. Field Crops Research, 122(3), 242247. https://doi.org/10.1016/j.fcr.2011.03.016

Kant, S. (2018, February). Understanding nitrate uptake, signaling and remobilisation for improving plant nitrogen use efficiency. In Seminars in Cell \& Developmental Biology(Vol. 74, pp. 89-96). Academic Press. https://doi.org/10.1016/j.semcdb.2017.08.034

Lacroix, A., Beaudoin, N., \& Makowski, D. (2005). Agricultural water nonpoint pollution control under uncertainty and climate variability. Ecological Economics, 53(1), 115-127. https://doi.org/10.1016/j.ecolecon.2004.11.001

Ladha, J. K., \& Reddy, P. M. (2003). Nitrogen fixation in rice systems: state of knowledge and prospects. Plant and soil, 252(1), 151-167. https://doi.org/10.1023/A:1024175307238

Lee, Y. J., Yang, C. M., Chang, K. W., \& Shen, Y. (2008). A simple spectral index using reflectance of $735 \mathrm{~nm}$ to assess nitrogen status of rice canopy. Agronomy Journal, 100(1), 205-212. https://doi.org/10.2134/agronj2007.0018

Li, G. H., Zhong, X. H., Tian, K., Huang, N. R., Pan, J. F., \& He, T. H. (2013). Effect of nitrogen application on stem lodging resistance of rice and its morphological and mechanical mechanisms. Scientia Agricultura Sinica, 46(7), 1323-1334. https://en.cnki.com.cn/Article_en/CJFDTotal-ZNYK201307004.htm

Li, X., Hu, C., Delgado, J. A., Zhang, Y., \& Ouyang, Z. (2007). Increased nitrogen use efficiencies as a key mitigation alternative to reduce nitrate leaching in north china plain. Agricultural Water Management, 89(1-2), 137-147. https://doi.org/10.1016/j.agwat.2006.12.012

Liang, T. A. N. G., XU, Z. J., \& CHEN, W. F. (2017). Advances and prospects of super rice breeding in China. Journal of integrative agriculture, 16(5), 984-991. https://doi.org/10.1016/S2095-3119(16)61604-0

Liang, W. H., Shang, F., Lin, Q. T., Lou, C., \& Zhang, J. (2014). Tillering and panicle branching genes in rice. Gene, 537(1), 1-5. https://doi.org/10.1016/j.gene.2013.11.058

Liao, Z., Yu, H., Duan, J., Yuan, K., Yu, C., Meng, X., ... \& Li, J. (2019). SLR1 inhibits MOC1 degradation to coordinate tiller number and plant height in rice. Nature communications, 10(1), 1-9. https://doi.org/10.1038/s41467-019$\underline{10667-2}$.

Liu, X., Zhang, Y., Han, W., Tang, A., Shen, J., Cui, Z., ... \& Zhang, F. (2013). Enhanced nitrogen deposition over China. Nature, 494(7438), 459-462. https://doi.org/10.1038/nature11917

Mae, T. (1997). Physiological nitrogen efficiency in rice: nitrogen utilization, photosynthesis, and yield potential. Plant and soil, 196(2), 201-210. https://doi.org/10.1023/A:1004293706242

Muñoz-Huerta, R. F., Guevara-Gonzalez, R. G., Contreras-Medina, L. M., Torres-Pacheco, I., Prado-Olivarez, J., \& Ocampo-Velazquez, R. V. (2013). A review of methods for sensing the nitrogen status in plants: advantages, disadvantages and recent advances. sensors, 13(8), 10823-10843. https://doi.org/10.3390/s130810823

Muthayya, S., Sugimoto, J. D., Montgomery, S., \& Maberly, G. F. (2014). An overview of global rice production, supply, trade, and consumption. Annals of the new york Academy of Sciences, 1324(1), 714. https://doi.org/10.1111/nyas. 12540

Normile, D. (2008). Reinventing rice to feed the world. Science, 321(5887), 330-333. https://doi.org/10.1126/science.321.5887.330

Patrick, R. M., Hoskins, F. H., Wilson, E., \& Peterson, F. J. (1974). Protein and amino acid content of rice as affected by application of nitrogen fertilizer. Cereal chemistry. https://agris.fao.org/agrissearch/search.do?recordID=US201303128106 
Peng, S., \& Cassman, K. G. (1998). Upper threshholds of nitrogen uptake rates and associated nitrogen fertilizer efficiencies in irrigated rice. Agronomy $\quad$ Journal, 90(2), 185. https://doi.org/10.2134/agronj1998.00021962009000020010x

Peng, S., Buresh, R. J., Huang, J., Yang, J., Zou, Y., Zhong, X., ... \& Zhang, F. (2006). Strategies for overcoming low agronomic nitrogen use efficiency in irrigated rice systems in China. Field Crops Research, 96(1), 37-47. https://doi.org/10.1016/j.fcr.2005.05.004

Salvagiotti, F., \& Miralles, D. J. (2008). Radiation interception, biomass production and grain yield as affected by the interaction of nitrogen and sulfur fertilization in wheat. European Journal of Agronomy, 28(3), 282-290. https://doi.org/10.1016/j.eja.2007.08.002

Samonte, S. O. P., Wilson, L. T., Medley, J. C., Pinson, S. R., McClung, A. M., \& Lales, J. S. (2006). Nitrogen utilization efficiency: relationships with grain yield, grain protein, and yield-related traits in rice. Agronomy journal, 98(1), 168176. https://doi.org/10.2134/agronj2005.0180

Stevens, C. J., Dise, N. B., \& Gowing, D. J. (2009). Regional trends in soil acidification and exchangeable metal concentrations in relation to acid deposition rates. Environmental pollution, 157(1), 313-319. https://doi.org/10.1016/j.envpol.2008.06.033

Sugimoto, T., Sueyoshi, K., \& Oji, Y. (1997). Increase of PEPC activity in developing rice seeds with nitrogen application at flowering stage. In Plant Nutrition for Sustainable Food Production and Environment (pp. 811-812). Springer, Dordrecht. https://doi.org/10.1007/978-94-009-0047-9

Sui, B., Feng, X., Tian, G., Hu, X., Shen, Q., \& Guo, S. (2013). Optimizing nitrogen supply increases rice yield and nitrogen use efficiency by regulating yield formation factors. Field Crops Research, 150, 99-107. https://doi.org/10.1016/j.fcr.2013.06.012

Tan, Q., Huang, G. H., \& Cai, Y. P. (2011). Radial interval chance-constrained programming for agricultural non-point source water pollution control under uncertainty. Agricultural Water Management, 98(10), 1595-1606. https://doi.org/10.1016/j.agwat.2011.05.013

Tao, M., Ma, X., Huang, X., Liu, C., Deng, R., Liang, K., \& Qi, L. (2020). Smartphone-based detection of leaf color levels in rice plants. Computers and Electronics in Agriculture, 173, 105431 https://doi.org/10.1016/j.compag.2020.105431

Tayefe, M., Gerayzade, A., Amiri, E., \& Zade, A. N. (2014). Effect of nitrogen on rice yield, yield components and quality parameters. African Journal of Biotechnology, 13(1), 91-105. https://doi.org/10.5897/AJB11.2298

Tian, Z., Li, Y., Liang, Z., Guo, H., Cai, J., Jiang, D., ... \& Dai, T. (2016). Genetic improvement of nitrogen uptake and utilization of winter wheat in the Yangtze River Basin of China. Field Crops Research, 196, 251-260. https://doi.org/10.1016/j.fcr.2016.07.007

ÜNAN, R., Sezer, I., ŞAHIN, M., \& Mur, L. A. (2013). Control of lodging and reduction in plant length in rice (Oryza sativa L.) with the treatment of trinexapac-ethyl and sowing density. Turkish Journal of Agriculture and Forestry, 37(3), 257-264. https://doi.org/10.3906/tar-1207-72

Vlek, P. L., \& Byrnes, B. H. (1986). The efficacy and loss of fertilizer N in lowland rice. In Nitrogen economy of flooded rice soils (pp. 131-147). Springer, Dordrecht. https://doi.org/10.1007/BF01048699

Wang, F., Cheng, F., \& Zhang, G. (2006). The relationship between grain filling and hormone content as affected by genotype and source-sink relation. Plant growth regulation, 49(1), 1-8. https://doi.org/10.1007/s10725-006-0017-3

Wang, Y., Ren, T., Lu, J., Ming, R., Li, P., Hussain, S., ... \& Li, X. (2016). Heterogeneity in rice tillers yield associated with tillers formation and nitrogen fertilizer. Agronomy Journal, 108(4), 17171725. https://doi.org/10.2134/agronj2015.0587

Xiong, Q., Tang, G., Zhong, L., He, H., \& Chen, X. (2018). Response to nitrogen deficiency and compensation on physiological characteristics, yield formation, and nitrogen utilization of rice. Frontiers in plant science, 9, 1075 https://doi.org/10.3389/fpls.2018.01075

Xu, H., Zhong, G., Lin, J., Ding, Y., Li, G., Wang, S., ... \& Ding, C. (2015). Effect of nitrogen management during the panicle stage in rice on the nitrogen utilization of rice and succeeding wheat crops. European Journal of Agronomy, 70, 41-47. https://doi.org/10.1016/j.eja.2015.06.008 
Xue, H., Tian, X., Zhang, K., Li, W., Qi, Z., Fang, Y., ... \& Ning, H. (2019). Mapping developmental QTL for plant height in soybean [Glycine $\max (\mathrm{L}$.$) Merr.] using a four-way recombinant inbred line population. PloS one, 14(11),$ e0224897. https://doi.org/10.1371/journal.pone.0224897

Xun, W., Zhao, J., Xue, C., Zhang, G., Ran, W., Wang, B., ... \& Zhang, R. (2016). Significant alteration of soil bacterial communities and organic carbon decomposition by different long-term fertilization management conditions of extremely low-productivity arable soil in S outh C hina. Environmental microbiology, 18(6), 19071917. https://doi.org/10.1111/1462-2920.13098

Yang, J., Chen, X., Zhu, C., Peng, X., He, X., Fu, J., ... \& He, H. (2014). Effects of nitrogen level and high temperature at late booting stage on yield and physiological characteristics of two early rice cultivars. Chinese Journal of Rice Science, 28(5), 523-533. https://doi.org/10.3969/j.issn.1001-7216.2014.05.010

Yang, J., Peng, S., Zhang, Z., Wang, Z., Visperas, R. M., \& Zhu, Q. (2002). Grain and dry matter yields and partitioning of assimilates in japonica/indica hybrid rice. Crop Science, 42(3), 766772. https://doi.org/10.2135/cropsci2002.7660

Yang, L., Huang, J., Yang, H., Dong, G., Liu, H., Liu, G., ... \& Wang, Y. (2007). Seasonal changes in the effects of freeair CO2 enrichment (FACE) on nitrogen $(\mathrm{N})$ uptake and utilization of rice at three levels of $\mathrm{N}$ fertilization. Field Crops Research, 100(2-3), 189-199. https://doi.org/10.1016/j.fcr.2006.07.003

Ye, C., Huang, X., Chu, G., Chen, S., Xu, C., Zhang, X., \& Wang, D. (2019). Effects of Postponing Topdressing-N on the Yield of Different Types of japonica Rice and Its Relationship with Soil Fertility. Agronomy, 9(12), 868. https://doi.org/10.3390/agronomy9120868

Yosef Tabar, S. (2012). Effect of nitrogen and phosphorus fertilizer on growth and yield rice (Oryza sativa L). International journal of agronomy and Plant Production, 3(12), 579-584. http://www.ijappjournal.com/wp-conten...

Yoshida, S. (1978). Tropical climate and its influence on rice. http://eprints.icrisat.ac.in/id/eprint/8613

Zeng, X., Han, B., Xu, F., Huang, J., Cai, H., \& Shi, L. (2012). Effects of modified fertilization technology on the grain yield and nitrogen use efficiency of midseason rice. Field Crops Research, 137, $203-212$. https://doi.org/10.1016/j.fcr.2012.08.012

Zhang, X., Dong, W., Dai, X., Schaeffer, S., Yang, F., Radosevich, M., ... \& Sun, X. (2015). Responses of absolute and specific soil enzyme activities to long term additions of organic and mineral fertilizer. Science of the Total Environment, 536, 59-67. https://doi.org/10.1016/j.scitotenv.2015.07.043

Zhang, Z., Chu, G., Liu, L., Wang, Z., Wang, X., Zhang, H., ... \& Zhang, J. (2013). Mid-season nitrogen application strategies for rice varieties differing in panicle size. Field Crops Research, 150, 9-18. https://doi.org/10.1016/j.fcr.2013.06.002

Zheng, S., Cao, H., Huang, Q., Liu, M., Lin, X., \& Li, Z. (2016). Long-term fertilization of P coupled with N greatly improved microbial activities in a paddy soil ecosystem derived from infertile land. European Journal of Soil Biology, 72, 14-20. https://doi.org/10.1016/j.ejsobi.2015.12.006

Zhong, X. H., Huang, N. R., \& Zheng, H. B. (2007). Some principles for the "three controls" nutrient management technology for irrigated rice. Guangdong Agric. Sci, 5, 19-22. https://en.cnki.com.cn/Article en/CJFDTotalGDNY200705005.htm

Zhou, W., Lv, T., Yang, Z., Wang, T., Fu, Y., Chen, Y., ... \& Ren, W. (2017). Morphophysiological mechanism of rice yield increase in response to optimized nitrogen management. Scientific reports, 7(1), 1-10. https://doi.org/10.1038/s41598-017-17491-y

ZHU, D. W., ZHANG, H. C., GUO, B. W., Ke, X. U., DAI, Q. G., WEI, H. Y., ... \& HUO, Z. Y. (2017). Effects of nitrogen level on yield and quality of japonica soft super rice. Journal of integrative agriculture, 16(5), 1018-1027. https://doi.org/10.1016/S2095-3119(16)61577-0 